TQM

19,3

274

\section{Determining the essential characteristics of Six Sigma Black Belts}

\section{Results from a pilot study in UK manufacturing companies}

\author{
Jiju Antony \\ Centre for Research in Six Sigma and Process Improvement (CRISSPI), \\ Caledonian Business School, Glasgow, UK \\ Alex Douglas \\ Liverpool John Moores University, Liverpool, UK, and \\ Frenie Jiju Antony \\ Strategy, Operations and Leadership, Caledonian Business School, \\ Glasgow, UK
}

\begin{abstract}
Purpose - The purpose of this research is to evaluate essential characteristics of Six Sigma Black Belts (SSBBs) in UK manufacturing organisations. Six Sigma Black Belt(s) are considered as high potential employees who work full-time as a leader of process and quality improvement projects after extensive training.

Design/methodology/approach - A pilot survey was undertaken to assess the key attributes of SSBBs. The results of this study are primarily based on descriptive statistics.

Findings - The key attributes of SSBBs identified from this pilot study include: effective communicators, change agents, customer advocators, team builders, results-driven mindset personnel, positive thinkers, etc. The findings of this study will be extremely beneficial in designing the curriculum of SSBBs citing the key attributes required for a typical SSBB to be successful.

Research limitations/implications - The study was primarily focused on manufacturing companies in the UK. The next phase of the study will be to compare the SSBB characteristics between manufacturing and service organisations. One of the authors will also be executing semi-structured interviews with SSBBs in various manufacturing and service companies to obtain a greater understanding of the essential attributes or characteristics that SSBBs in manufacturing and service companies must possess.

Originality/value - Although the characteristics of SSBBs are cited widely in various textbooks and professional articles, no empirical study has been carried out to compare the theory and practice. This paper makes an attempt to identify essential characteristics of SSBBs in UK manufacturing companies.
\end{abstract}

Keywords Six Sigma, Quality, Manufacturing industries, Service industries, United Kingdom

Paper type Research paper

\section{Introduction}

The TQM Magazine

Vol. 19 No. 3, 2007

pp. $274-281$

(C) Emerald Group Publishing Limited 0954-478X

DOI $10.1108 / 09544780710745685$
A Six Sigma Black Belt (SSBB) plays the role of a full-time team leader responsible for implementing process improvement projects using the Six Sigma methodology (Define-Measure-Analyse-Improve-Control) within the business to drive up customer 
satisfaction levels and business productivity. Black Belt projects are typically defined so that they can be completed in less than 6 months, and are generally focused on high-priority business issues and are targeted to add $\$ 175,000$ to $\$ 250,000$ to the bottom-line of organisations (Snee, 2004). A fully trained BB will be expected to deliver a minimum of $\$ 500,000$ to well over $\$ 1,000,000$ in direct cost savings to the bottom-line of an organisation per year (Harry and Schroeder, 2000). Moreover, a BB is expected to complete between 4 to 6 projects per annum depending on the scope of the project, complexity of the project and availability of data. The BB program of study focuses on an understanding of the Six Sigma philosophy, key principles and concepts, tactics, application of tools and techniques, project management skills, etc. So,why the martial arts terminology? The sole function of a $\mathrm{BB}$ is to focus on disciplined problem solving using the DMAIC (Define-Measure-Analyse-Improve-Control) methodology and a specific set of tools and techniques with speed (i.e. project completion in a short period of time). The purpose here is to defeat the enemy - variation in processes which lead to customer dissatisfaction (Brue and Howes, 2006).

\section{Black belts and their characteristics: a review of literature}

The term Six Sigma BB was first introduced by the Motorola Corporation to describe employees who are trained and experienced in applying statistical techniques to business processes so that they can make significant contributions to the bottom-line (Measuring Business Excellence, 2002). Black Belts (BBs) are so critical to achieving successful outcomes of Six Sigma projects and therefore the selection of such candidates for the Six Sigma projects is absolutely crucial. In order to successfully choose BBs for Six Sigma projects, organisations should determine what attributes (in general) to look for and what personal characteristics do they possess that make them attractive candidates to executing, leading and deploying projects. Six Sigma provides the opportunity for BBs to be leaders of business improvement. BBs are hands-on workers, begin devoted full time to their projects, and do much of the detailed work. BBs receive four weeks of training: one week per month over a four-month period of time with 3 to 4 weeks between sessions for selecting the projects which are aligned with strategic objectives of the business (Snee and Hoerl, 2005). A Black Belt candidate should be:

- a self-starter who can work on their own initiative;

- able to lead, mentor and work in a team;

- an effective communicator at all levels;

- computer literate and competent in elementary statistics; and

- energetic, enthusiastic and have a passion for excellence, and so on.

According to Hoerl (2001), when searching for a BB candidate the desirable qualities include a mix of technical aptitude, leadership skills and soft skills such as meeting management. The generic nature of a $\mathrm{BB}$ assignment, in addition to its rigorous process discipline and relentless customer focus makes Six Sigma the perfect training for growing 21st century GE leadership. Harry and Schroeder (2000) list the following characteristics to be considered as an effective BB:

- ability to understand the "big picture" of the business;

- possesses excellent communication skills, both written and verbal;

\section{Six Sigma Black Belts}

275 
TQM

19,3

\section{6}

- inspires others to excel;

- allows room for failures and mistakes with a recovery plan;

- focuses on results and understands the importance of the bottom-line;

- encourages commitment, dedication and teamwork;

- promotes win-win solutions;

- more concerned about business success than personal gain; and

- recognises that results count more than fancy titles and silk night shirts, etc.

Adams et al. (2003) have come up with the following criteria for the selection of Black Belt candidates:

- Performance. Do not select the people for BB training that no one else in the company wants.

- Management potential. Experience in managing people and also to leading a team of people.

- Technical capability. Demonstrate the technical competency by showing how various tools and techniques of Six Sigma can be applied to a problem solving scenario.

- Self-starter. Select the people who have initiative.

- Problem-solving ability. Select the people who have the skills to tackle problems using disciplined and systematic approaches.

- Process oriented mindset. Select those people who view all activities as processes with inputs, outputs and controls.

- Passionate-about the application of Six Sigma methodology and tools. People who do not want to be BBs will probably go through the motions, but their hearts and minds will not be in it.

Black and McGlashan (2004) have carried out a survey in the United States in the summer of 2004. Over 300 Six Sigma companies had participated in the survey. The study was carried out to understand the key characteristics of SSBBs in the USA companies. The top eight characteristics identified from this study were:

(1) change agent;

(2) problem-solving ability;

(3) results-oriented;

(4) reasoning skills;

(5) team builder;

(6) initiative;

(7) customer-oriented; and

(8) self-confident (positive thinker).

Snee and Hoerl (2003) recommended to look for the following key attributes in SSBBs:

- technical leader in the area of the project;

- analytical thinker; 
- able to lead teams - "soft skills" (communication, mentoring etc.);

- computer literate;

- project management skills;

- positive mindset or positive thinker; and

- basic statistical skills, etc.

The following attributes are highlighted in the BB Memory Jogger produced by GOAL QPC (2002):

- responsible for leading, executing and completing Six Sigma DMAIC projects;

- teaches team members the DMAIC methodology and the tools and techniques of Six Sigma;

- assists in identifying problem areas, scoping projects and refining project details;

- reports progress reports to Six Sigma project champions and the process owners; and

- mentors Six Sigma Green Belts.

Brue and Howes (2006) identify the following essential characteristics for a SSBB:

- ability to work on their own and also in groups;

- anticipate problems and act on them accordingly;

- inspire others;

- concerned about the current processes and results, and they want to improve the system;

- desire to drive change;

- open-minded;

- respect their fellow workers and are respected by them;

- eager to learn about new ideas; and

- ability to solve problems using data-driven methodology (DMAIC), etc.

\section{Research objectives and methodology}

The fundamental objective of this study was to "determine the essential characteristics of SSBBs in UK manufacturing organisations". In order to do this effectively, the general objective was further divided into a number of specific research questions as follows:

$R Q 1$. What are the roles and responsibilities of Six Sigma Black Belts (SSBBs)?

RQ2. What are the essential characteristics of SSBBs in UK manufacturing companies?

RQ3. Can SSBBs be viewed as potential high-leaders in the participant companies?

In this study, a total of 200 questionnaires were sent to manufacturing companies. The questionnaire was designed and adapted based on the work of a similar study carried out in the US industry (Black and McGlashan, 2004). The response rate from the 
TQM

19,3

278

companies was about 25 per cent (i.e. 50 companies). However just 24 companies were engaged in the Six Sigma program as part of their quality improvement strategy. The list of companies was obtained from two databases (FAME and Global Access).

It was decided to use mail and self-administered questionnaire (postal survey) as the data collection instrument. The advantages of this approach to data collection are (Nueman, 2003; Sarantakos,1998):

- inexpensive;

- results are produced in a short period of time;

- questionnaires are completed in the respondents' convenience;

- anonymity is greatly assured; and

- respondents are at liberty to provide objective views on sensitive issues.

All the essential characteristics in the questionnaire were generated by thoroughly reviewing existing literature (Hoerl, 2001; Brue and Howes, 2006; Snee and Hoerl, 2005; Harry and Schroeder, 2000; Keller, 2001; Waxer, 2005; Adams et al., 2003 and Black and McGlashan, 2004).

\section{Analysis of results and key findings}

The majority of the respondents (about 90 per cent) to the questionnaire were Six Sigma Black Belts (SSBBs) and 10 per cent respondents were Six Sigma Deployment Champions. The type of companies responded to this survey include: automotive (30 per cent), electronics and semi-conductors ( 25 per cent), plastics (15 per cent), aerospace (10 per cent), chemicals ( 5 per cent), transportation( 5 per cent), etc. The number of SSBBs in participative companies varied from 5 to over 200.

It was noted that 63 per cent of the organisations (15 companies) involved in the survey have been using Six Sigma for more than 8 years on average. 33 per cent of the organisations (8 companies) have been engaged in Six Sigma program for 5 to 8 years and 1 company claimed (4 per cent) to have been using Six Sigma for less than 5 years. The average sigma quality level of the companies was between 2.9 and 3.4. The authors strongly believe that this figure might change with the increased sample size.

The following table (refer to Table I) shows the mean responses of top 12 essential attributes for Six Sigma Black Belts (SSBBs). The respondents were asked to rate each

Table I.

Attributes and their mean scores

\begin{tabular}{lc}
\hline Attributes & Mean score \\
\hline Effective communicator & 4.813 \\
Team builder & 4.750 \\
Results-oriented personnel & 4.725 \\
Change agent & 4.716 \\
Customer advocate & 4.650 \\
Positive thinker & 4.630 \\
Motivated to lead & 4.500 \\
Problem-solving ability & 4.325 \\
Respect for others & 4.210 \\
Innovative & 4.106 \\
Networking ability & 4.084 \\
Risk taker & 4.021 \\
\hline
\end{tabular}


attribute on a Likert Scale of 1 to 5, $1=$ least important and $5=$ most important. The higher the score, the more important the attribute will be.

According to the mean scores, effective communicator was perceived as being the most essential characteristic with a mean score of 4.813 , followed by team builder with a mean score of 4.750 , results oriented personnel with a mean score of 4.725 , change agent with a mean score of 4.716 and customer advocate with a score of 4.650 . Others in the top ten included positive thinker (4.630), motivated to lead (4.500), problem solving ability (4.325), respect for others (4.210) and innovative (4.106).

The characteristics which were rated very low with a mean score of less than 3.5 included Loyal, Charisma, Empathetic, Organisational commitment and Writing skills. We also compared the attributes of SSBBs according to the number of BBs a company already possessed. For analysis purposes, we have classified organisations into two groups: organisations with 100 or less Black Belts and organisations with more than 100 Black belts. Table II displays the mean scores for the top-rated characteristics (only top 6 are shown) by each respondent whose company falls into these two categories.

It has been observed from Table II that both groups rated "Team Builder" and "Results oriented Personnel" highly. The characteristic "Effective Communicator" rated very high by the more than 100 Black Belts group. This characteristic has also appeared in the less than 100 Black Belt group. Characteristics, such as "Motivated to Lead" and "Problem Solving Ability," were not listed to be important by the less than 100 Black Belt group. Similarly, characteristic, such as "Change Agent" and "Positive Thinker", were not listed to be important by the more than 100 Black Belt groups, which was rather surprising to the authors.

Table III provides a comprehensive list of 8 essential attributes of SSBBs and the essential characteristics of SSBBs obtained from our study in the UK manufacturing companies.

Table III illustrates that the first four characteristics among top five are common in all cases except for Kodak SSBB attributes. So we strongly believe that the top five essential attributes of SSBBs are:

(1) leadership;

(2) change agent;

(3) effective communicator;

(4) team builder; and

(5) results-oriented personnel.

\begin{tabular}{|c|c|c|c|c|}
\hline Characteristic (100 or fewer than $100 \mathrm{BBs}$ ) & $\begin{array}{l}\text { Mean } \\
\text { score }\end{array}$ & Characteristic (more than $100 \mathrm{BBs}$ ) & $\begin{array}{l}\text { Mean } \\
\text { score }\end{array}$ & \\
\hline Team builder & 4.821 & Effective communicator & 4.940 & Table II. \\
\hline Results-oriented personnel & 4.780 & Team builder & 4.681 & Characteristic mean \\
\hline Change agent & 4.646 & Results-oriented personnel & 4.672 & scores for companies with \\
\hline Positive thinker & 4.642 & Customer advocate & 4.668 & 100 or fewer than $100 \mathrm{BBs}$ \\
\hline Effective communicator & 4.680 & Motivated to lead & 4.630 & and companies with over \\
\hline Respect for others & 4.476 & Problem-solving ability & 4.434 & $100 \mathrm{BBs}$ \\
\hline
\end{tabular}

\section{Six Sigma Black Belts}

279

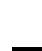




\section{TQM \\ 19,3}

\section{0}

\section{Table III.}

A comparative study of the essential characteristics of SSBBs

\begin{tabular}{|c|c|c|c|c|c|}
\hline $\begin{array}{l}\text { Kodak SSBB } \\
(2005)\end{array}$ & $\begin{array}{l}\text { Kodak SSBB } \\
\text { (2005) }\end{array}$ & $\begin{array}{l}\text { Keller } \\
(2001)\end{array}$ & $\begin{array}{l}\text { Waxer } \\
(2005)\end{array}$ & $\begin{array}{l}\text { Harry and Schroeder } \\
(2000)\end{array}$ & $\begin{array}{l}\text { Antony et al. } \\
\text { (2006) }\end{array}$ \\
\hline Leadership & $\nu$ & レ & レ & レ & $\nu$ \\
\hline Change agent & レ & レ & レ & レ & レ \\
\hline Communicator & $x$ & レ & $\nu$ & レ & $\boldsymbol{\nu}$ \\
\hline Team builder & レ & レ & $x$ & $x$ & レ \\
\hline Results-oriented personnel & $x$ & $x$ & $\nu$ & $\nu$ & $\boldsymbol{\nu}$ \\
\hline Customer advocate & $x$ & $x$ & $\boldsymbol{\nu}$ & $x$ & $\boldsymbol{\nu}$ \\
\hline Respected by peers & $x$ & レ & $\boldsymbol{\nu}$ & $\boldsymbol{\nu}$ & $x$ \\
\hline Technical aptitude & レ & $x$ & $レ$ & $x$ & $\times$ \\
\hline
\end{tabular}

\section{Conclusion and future research}

The paper illustrates the role and the essential attributes of Six Sigma Black Belts (SSBBs). The authors make an attempt to compare the essential attributes of SSBBs proposed by many practitioners and academics who have carried out research in the field. The top five essential characteristics for a SSBB include: effective communicator, team builder, results-oriented personnel, change agent and customer advocate. The next phase of the study is to carry out a number of semi-structured interviews with a number of Black Belts in the participative companies for obtaining a greater insight into these characteristics. Moreover, a comparative study of SSBBs in UK service organisations will be quite beneficial to the Six Sigma research and practitioners community. One of the major limitations of our study is the limited sample size used for the research. The authors are planning to carry out this study with a much larger sample size and a comparative study of Six Sigma Black Belts characteristics across various industry sectors (automotive, plastics, chemicals, banks, financial services, utility services, etc.) will also be performed. In particular, the authors believe that the number of the current Six Sigma Black Belts in service organizations should increase, noting that service operations now comprise more than 80 per cent of the GDP in the United States and are rapidly growing around the world. The future study will also look into the limitations of being SSBB in organisations and how SSBB curriculum could be adjusted to overcome such limitations. The authors also believe that the curriculum of SSBBs in different countries vary significantly and therefore a standard SSBB curriculum for different types of sectors is highly desirable in the forthcoming years. Finally, the authors believe that the concept of linking Six Sigma efforts to shareholder value is critically important but seldom discussed by researchers. We identify this as a critical research area because if the link is not made, companies may realize some gains, but it will be crapshoot as to whether investment in Six Sigma will help drive strategic goals.

\section{References}

Adams, C., Gupta, P. and Wilson, C. (2003), Six Sigma Deployment, Elsevier Science, Oxford.

Antony, J., Kumar, A. and Banuelas, R. (Eds) (2006), World Class Applications of Six Sigma, Elsevier Science, Oxford. 
Black, K. and McGlashan, R. (2004), "Essential characteristics for Six Sigma Black Belt candidates: a study of US companies", 1st International Conference on Six Sigma, Glasgow, 16-17 December, 2004, pp. 178-91.

\section{Six Sigma Black Belts}

Brue, G. and Howes, R. (2006), The McGraw-Hill 36 Hour Course on Six Sigma, McGraw-Hill, New York, NY.

GOAL/QPC (2002), GOAL/QPC The Black Belt Memory Jogger, 1st ed., GOAL/QPC, Salem, NH.

Harry, M. and Schroeder, R. (2000), Six Sigma: the Breakthrough Management Strategy revolutionizing the World's Top Corporations, Currency Doubleday, New York, NY.

Hoerl, R.W. (2001), "Six Sigma Black Belts: what do they need to know?", Quality and Reliability Engineering International, Vol. 33 No. 4, pp. 391-406.

Keller, P.A. (2001), Six Sigma Deployment: A Guide for Implementing Six Sigma in Your Organisation, Quality Publishing, Houston, TX.

Kodak (2005), Kodak Six Sigma Black Belt, available at: www.kodak.com/US/en/corp/ researchdevelopment/careers/SixSigma.html (accessed October 2006).

Measuring Business Excellence (2002), "GE and Motorola belt up for Six Sigma success", Measuring Business Excellence, Vol. 6 No. 3, pp. 64-7.

Nueman, W.L. (2003), Social Research Methods: Qualitative and Quantitative Approaches, 5th ed., Pearson Education Inc., Upper Saddle River, NJ.

Sarantakos, S. (1998), Social Research, 2nd ed., Macmillan, London.

Snee, R.D. (2004), "Six Sigma: the evolution of 100 years of business improvement methodology", International Journal of Six Sigma and Competitive Advantage, Vol. 1 No. 1, pp. 4-20.

Snee, R.D. and Hoerl, R.W. (2003), Leading Six Sigma, Prentice-Hall, Englewood Cliffs, NJ.

Snee, R.D. and Hoerl, R.W. (2005), Six Sigma beyond the Factory Floor, Prentice-Hall, Englewood Cliffs, NJ.

Waxer, C. (2005), Top Ten Six Sigma Black Belt Candidate Qualities, available at: www. isixsigma.com/library/content/

\section{Corresponding author}

Jiju Antony can be contacted at: J.antony@gcal.ac.uk

To purchase reprints of this article please e-mail: reprints@emeraldinsight.com Or visit our web site for further details: www.emeraldinsight.com/reprints 